\title{
Research on Civil Engineering Waste Management for Collapsible Soils
}

\author{
Abhishek Sharma, AK Gupta, Kongan Aryan
}

\begin{abstract}
Civil engineering wastes can be widely used in field for stabilization of collapsible soil. Civil wastes can be used to improve the bearing capacity and settelementbehavior of collapsible soil in an economic construction costs and environment friendly also. The various types of civil wastes can be used to improve the overall strength of collapsible soils. The areas in India which are only prone to collapsible or black cotton soils do not have any other options. Hence civil wastes can be used to increase the overall strength of such soils.

In this paper, the deatailed experimental investigation was done to study the complete use of civil wastes for collapsible and black cotton soil, also a detailed study was done to check the other ways and processes of complete use of civil and construction industry wastes. The various tests were performed with soil samples containing $0 \%, 1 \%, 2 \%, 5 \%, 10 \%$ and $15 \%$ of civil wastes with $15 \%$ of cement by mass of soil.

Keywords-:Civil wastes *Collapsible soil *Environmental applications *Civil engineering applications *Predictions of air pollution in Delhi ncr.
\end{abstract}

\section{INTRODUCTION}

India is a subcontinent country and there are many varieties ofsoil samples found in different regions. Especially there are many regions which are prone to a particular variety of soil sample and there are less options in such areas.Following are types of soil found in different regions of India-

Alluvial Soil- Mainly found in plains of Gujrat,Punjab,Haryana,UP and Bihar.

Black(regular soil)- Found in Deccan platueMaharashtra,MadhyaPradesh,Gujrat and Tamil Nadu.

Red soil- Found in east and southern part of Deccan platuei.e Odisha, Chattisgarh.

Laterite Soil- Found in Karnataka,Kerela,Tamilnadu and Odisha.

Arid soil- Found in North Gujarat,Southern Punjab and Rajasthan. It is resistant to drought.

Saline and Alkaline- Found in western Gujarat,Eastern delta, Punjab and Haryana.

Revised Version Manuscript Received on 19 August, 2019.

Abhishek Sharma, $2^{\text {nd }}$ Year Environmental Engineering DTU India, Diploma In Civil Engineering, Board Of Technical Education, Department of Environmental engineering and Civil engineering, Delhi Technological University, Delhi, India.

(email: : jayamaniraaja07@gmail.com)

Prof.AK Gupta, Civil And Environmental Engg. Advisor DTU, Department of Environmental engineering and Civil engineering, Delhi Technological University, Delhi, India.

Prof. Kongan Aryan, Expert And Guide Civil And Environmental Engg.(Doctorate/Research Jimma University Africa) DTU, Department of Environmental engineering and Civil engineering, Delhi Technological University, Delhi, India.

\section{COLLAPSIBLE SOIL-}

Collapsible soils consist of loose, dry,low density materials that collapse and compact on addition of water or excessive loading. The soil collapse occours when land surface is saturated at depths or areas more prone to rainfall. It results in structural damage such as cracking of foundation, floors and walls in response to settelement. In India these soil are also called bl;ack cotton soil.Collapsible soils are less used in construction purposes.

\section{CIVIL ENGINEERING WASTES}

Very fine wood particles,glasspowders,steelpyrites,some particles of broken or unused bricks,some left out concrete(in crushed form). These all the particles were thoroughly mixed and coverted in powdery form and around 300grams of mixed fine particles were used in mixing with soil and performing comopaction test. Civil engineering wastes were taken from construction sites of north MCD and type 5 construction sites of DTU.

Also some of the data of use of civil industry waste were taken from the Construction and demolition plant of MCD located in Burari Delhi. Plant operation started on 24/07/2009 and data was taken upto- 16/12/2018. Total waste received till above date is 41.27 Lakh MT and waste processed till now is 37.40 Lakh MT.

\section{Why Waste to soil additive :-}

As we know additive or admixture are added before make cement to concrete to gain properties or to improve their chemical and physical properties. Actually after adding civil waste the soil gain more tensile as well as compressive strength then normal.

Civil waste concede iron powder too which add tensile strength to the soil that means it protect it from failure in tensile.

Wastes are always use to dump and it cause or convert land into landfills after our use we can avoid this too which make it environmental friendly.

The objectives and scope of present study are:

1. To find the optimum value of collapsible soil sample containing civil engineering wastes at various values.

2. To determine the value of compaction test of soil containing civil engineering waste.

3. To make the soil more environment friendly by using waste as ingredients.

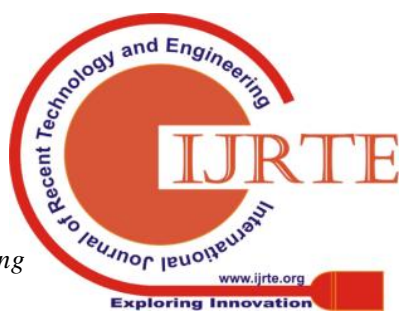


Tests perform on soil containing civil waste:-

Two Major soil tests were performed in soil samples containing civil wastes i.e.

Compaction Test

California bearing Ration tests.

*Soil samples were taken from type 5 construction site of DTU*

The tests were performed in Transportation laboratory of DTU

\section{COMPACTION TEST \& RESULTS}

This test is used for determining maximum dry density (Y-max) \& Optimum moisture content (Wopt) of soil.

\begin{tabular}{|l|l|l|l|}
\hline S. NO. & $\begin{array}{l}\text { Expansive soil } \\
\%\end{array}$ & $\begin{array}{l}\text { Cement\% by } \\
\text { mass of soil }\end{array}$ & $\begin{array}{l}\text { Civil waste } \\
\text { powder \%by } \\
\text { mass of soil }\end{array}$ \\
\hline 1 & 100 & 15 & 0 \\
\hline 2 & 100 & 15 & 1 \\
\hline 3 & 100 & 15 & 2 \\
\hline 4 & 100 & 15 & 5 \\
\hline 5 & 100 & & 10 \\
\hline 6 & 100 & 15 & 15 \\
\hline
\end{tabular}

\section{C\&D PLANT, BURARI DELHI}

- Total waste received till now : 41.27 Lakh MT

- Totalwasteprocessedtillnow: 37.40LakhMT

- Theplantoperationstartedon24/07/2009andaboveprovid eddataisupto16/12/2018

\section{ENVIRONMENTAL EFFECTS OF CIVIL ENGINEERING WASTES}

- Wood dust becomes potential health problem when wood particles from processes such as sanding \& cutting becomes airborne.

- Breathing these particles may cause allergic respiratory Symptoms, mucosal \& non allergic respiratory symptoms \& Cancer.

- The transportation and construction work itself of such materials can cause harm on environment.

- These wastes effect green house effects because of emission of carbon di oxide.

Following is result of Compaction Test with or without Civil Waste:-

\begin{tabular}{|c|c|c|c|c|c|c|}
\hline & $\begin{array}{l}0 \% \quad \mathrm{C} . \\
\mathrm{W} \\
15 \% \mathrm{CE} \\
\mathrm{MENT}\end{array}$ & $\begin{array}{l}1 \% \\
\text { C.W+ } \\
15 \% \\
\text { ceme } \\
\text { nt }\end{array}$ & $\begin{array}{l}2 \% \\
\text { C.W+ } \\
15 \% \\
\text { ceme } \\
\text { nt }\end{array}$ & $\begin{array}{l}5 \% \\
\text { C.W+ } \\
15 \% \\
\text { ceme } \\
\text { nt }\end{array}$ & $\begin{array}{l}10 \% \\
\text { C.W+ } \\
15 \% \\
\text { ceme } \\
\text { nt }\end{array}$ & $\begin{array}{l}15 \% \\
\text { C.W+ } \\
15 \% \\
\text { ceme } \\
\text { nt }\end{array}$ \\
\hline $\begin{array}{l}\text { MD } \\
\text { D } \\
\text { KN/ } \\
\text { M3 }\end{array}$ & 25.37 & 25.79 & 25.87 & 25.90 & 25.67 & 25.32 \\
\hline $\begin{array}{l}\mathrm{OM} \\
\mathrm{C} \%\end{array}$ & 16.40 & 15.70 & 15.25 & 14.96 & 14.27 & 14.09 \\
\hline
\end{tabular}

As per value here is the conclusion and result :-

- The research concluded that improvement in property of Expansive soil was obtained \& therein more significant in Powdered Civil Waste. The percentage of Powdered Civil Waste for obtaining best result was Lyeing between $5 \%$ \& $10 \%$ by mass of soil.

- Maximum values of Shear strength test was obtained at $10 \%$ Civil Waste Powder content.

- It is concluded that powdered form of Civil waste like wood powder, glass powder can be used as soil stabilizer \& it will save i.e. expensive soil from moisture content $\&$ sudden demolition of structures can be stopped.

- Reducing civil wastes can be helpful in improving air quality index of Delhi Ncr.

\section{LITERATURE REVIEW}

1. Dr. Raju Sarkar et.al[11] represents a study of the lime and stone dust as the admixtures or stabilizers in improving some engineering Properties of Black cotton (BC) soils. This experimental program evaluates the effect of the lime and stone dust on the some basic engineering properties of $\mathrm{BC}$ soil such as Specific gravity, Atterberg's limits, compaction characteristics and California bearing ratio of $\mathrm{BC}$ soil. By weight of the mixture of Lime-Black cotton soil the percentage of stone dust was used upto $25 \%$. It was observed that MDD of lime stabilized $(=9 \%)$ Black Cotton Soil increases up to the addition of $20 \%$ Stone Dust and further increase of the agent decreases the value. Similarly, for UCS and CBR, the Strength increases up to $20 \%$ addition of Stone Dust in lime stabilized soil. The reason of this effect is the pozzolanic reactions of lime with the amorphous silica and alumina present in soil and Stone Dust. SEM Pictures of cured sample clearly shows coarser bonded particles of Black Cotton Soil, Lime and Stone Dust X-Ray diffraction os samples shows the presence of Montmorillonite.

Patil and Patil [12] studied the improvement in properties of sub-grade soil by using moorum and RBI Grade 81 . With an increase of cost, RBI grade 81 proved to be an economical method where as moorum are weathered rock fragments which are gravely and non-plastic in nature.

2. The standard proctor's test was done on untreated soil with a value of MDD was $1.43 \mathrm{~g} / \mathrm{cc}$ and OMC was $25.80 \%$. same test was also performed for soil reinforced with RBI Grade 81 and with the different proportions of RBI Grade 81 to soil. The maximum value of soil to RBI Grade 81 obtained with a ratio of $96: 4$ with a value of MDD $1.45 \mathrm{~g} / \mathrm{cc}$ and OMC $26.16 \%$ and in case of soil to moorum the maximum value of MDD $1.53 \mathrm{~g} / \mathrm{cc}$ with an optimum content $24.85 \%$. According to IRC, the pavement thickness is $2 \mathrm{msa}$ having CBR value of sub grade soil $2.56 \%$ is $660 \mathrm{~mm}$ and if same soil is treated with $2 \%$ RBI Grade 81, CBR value increased up to $4.89 \%$ and ultimately the total pavement thickness reduced up to 520 $\mathrm{mm}$. It can be concluded that with an increase in percentage of moorum, the OMC of soil reduces and MDD increases. Fig. 3 depicts the effect of moorum and RBI Grade 81 on MDD, OMC and soaked CBR values of soil. Fig. 4 depicts 
the effect of RBI Grade 81 and moorum on CBR value of soil.

3. Tiwari et.al[12] has conducted experimental study n 48 trial samples test were carried in two phase such as in first phase, the physical properties of soil such as hygroscopic moisture content grain size distribution, specific gravity. Atterberg's limits, Direct shear test, Swelling pressure, MDD-OMC, CBR, Permeability test values are determined. In second phase, various test investigation performed on black cotton soil using different percentages of Fly Ash (FA) at $10 \%, 15 \%, 20 \%, 25 \%$, Coconut Coir Fiber (CCF) at $0.25 \%$, $0.5 \%, 0.75 \%, 1 \%$ \&amp; Crushed Glass (CG) at 3\%, 5\%, $7 \%$.And observed that addition of Fly Ash, Coconut Coir Fibre (CCF), and Crushed Glass (CG) in Black Cotton Soil improves the Engineering properties of soil.

\section{RESULT}

As per research we may conclude that civi waste is higherly impact on improving quality of soil as well environment.

\section{REFERENCES}

1. Analysis of Rigid Pavements for collapsible soil by Dr. Kongan Aryan \& A.K. Gupta.

2. Mudgal, A., Sarkar, R. and Sahu, A.K., (2014), "Effect Of Lime And Stone Dust In The Geotechnical Properties Of Black Cotton Soil", International Journal of GEOMATE, Vol. 07, No. 02, pp. 1033-1039.

3. https://en.wikipedia.org/wiki/Geosynthetics\#Geotextiles

4. Geo Textile: It's Application To Civil Engineering Overview

5. Dr. Bipin J Agrawal, "'Geo Textile: It's Application To Civil Engineering - Overview", National Conference on Recent Trends in Engineering \& Technology, pp.1-6.

6. Vashi, Jigisha M, Desai, Solanki, C.H., "Geosynthetic Materials and its Properties for Reinforced Earth Structures", pp. 1-12

7. Dr. K. R. Arora, "Soil Mechanics And Foundation Engineering", ISBN81/8014/028/8.

8. Amit Harihar Padade J. N. Mandal, "Behaviour of Expanded Polystyrene (EPS) Geofoam Under Triaxial Loading Conditions", Electronic Journal Of Geotechnical Engineering, Vol. 17 [2012], pp. 2543-2553.

9. Debasree Pal, Dr. Sujit Kumar Pal, "Consolidation characteristics of Soil-Porous Geotextile, Electrical Journal Of Geotechnical Engineering, Vol. 19 [2014] pp 3541-3542.

10. A.K.Choudhary, K.S.Gill and J.N.Jha , "Improvement in CBR values of expansive soil sub-grades using geo-synthetics" IGC J-233.

11. Ankur Mudgall, Raju Sarkar2 and A.K. Sahu2, "Effect Of Lime And Stone Dust In The Geotechnical Properties Of Black Cotton Soil".Int. J. of GEOMATE, Dec., 2014, Vol. 7, No. 2 (SI. No. 14), pp. 1033-1039.

12. Patil, B.M. and Patil, K.A., (2013), "Improvement in Properties of Subgrade Soil by Using Moorum and RBI Grade 81", International Journal of Scientific \& Engineering Research, Vol. 04, No. 05, pp. 289-292. 